\title{
Alternatives to broadcast burning in the northern interior of British Columbia: Short-term tree results
}

\author{
by J.M. Kranabetter ${ }^{1}$ and D. Yole ${ }^{2}$
}

\begin{abstract}
We compared the growth and foliar nutrients of lodgepole pine and hybrid white spruce following mechanical site preparation treatments and broadcast burning in a high-elevation plantation in north-central British Columbia. After five years, the largest trees were found on the broadcast burn ( $44 \%$ increase over raw planting), followed by disc-trenching ( $26 \%$ increase), and then windrow piling ( $9 \%$ increase). Height increment was similarly significantly different between treatments after seven years. Equal increases in nitrogen, phosphorus, and sulphur foliar concentrations were found across all site preparation treatments compared to controls. Foliar nutrients alone, however, did not further explain the differences in tree productivity between site preparation treatments. The results demonstrated how some sites can benefit from site preparation, in the short-term at least, and also emphasized the positive role fire can have on forest productivity.
\end{abstract}

Key words: mechanical site preparation, broadcast burning, Picea gluaca, Pinus contorta

Nous avons comparé la croissance et les éléments nutritifs des aiguilles de pin lodgepole et d'un hybride d'épinette blanche suite à une préparation mécanique du sol et d'un brûlage dirigé dans une plantation de haute altitude du centre-nord de la Colombie-Britannique. Après cinq ans, les arbres les plus gros ont été retrouvés dans les stations de brûlage dirigé (44\% supérieur à la plantation brute), suivis des stations scarifiées à la herse ( $26 \%$ supérieur), et puis par la mise en andain ( $9 \%$ supérieur). L'accroissement en hauteur était significativement différente entre les traitements après sept ans. Des augmentations équivalentes des concentrations foliaires d'azote, de phosphore et de sulfure ont été retrouvées dans toutes les stations préparées comparativement aux témoins. Cependant, les éléments nutritifs individuellement n'ont pas expliqué plus en profondeur les différences de la productivité des arbres entre les traitements de préparation du sol. Les résultats ont démontré comment certaines stations pouvaient tirer bénéfice de la préparation du sol, du moins à court terme, et ont également souligné le rôle positif que le feu peut avoir sur la productivité forestière.

Mots-clés: préparation mécanique du sol, brûlage dirigé, Picea glauca, Pinus contorta

\section{Introduction}

Site preparation with broadcast burning has been an effective tool in forest management in British Columbia, but its use has declined substantially in recent years due to increasing costs, risks and restrictions compared to mechanical treatments. Three of the more common alternatives to broadcast burning in the north-central interior of British Columbia have been disctrenching, windrow piling, and raw planting. The costs and benefits, in terms of short-term and long-term site productivity, of this shift away from broadcast burning to alternative treatments are not fully known.

While there is a large amount of research on fire and mechanical site preparation effects on soils, there are fewer studies directly comparing tree growth from these treatments. Broadcast burning in the Cascade Range of western Oregon and Washington lead to increases in site index by as much as $10 \%$, but no consistent differences over unburned plots were found after approximately 40 years (Miller and Seidel 1990). Broadcast burning favoured Douglas-fir growth in Oregon compared to other site preparation treatments (Stein 1997), while longer-term results from Sweden showed inconsistent effects of burning compared to site preparation with Scot's pine (Örlander et al. 1996).

Early results of our study comparing site preparation treatments in a high-elevation forest showed improved microclimate and soil nutrient availability for broadcast burning and disc-trenching compared to windrow piling and controls (Yole and Kranabetter 1996). In this note we report on the fifth

${ }^{1}$ BC Ministry of Forests, Bag 5000, Smithers, B.C. V0J 2N0. E-mail: Marty.Kranabetter@GEMS5.GOV.BC.CA

${ }^{2}$ Soils consultant, Comp. 10 Site 8 RR\#1, Telkwa, B.C.

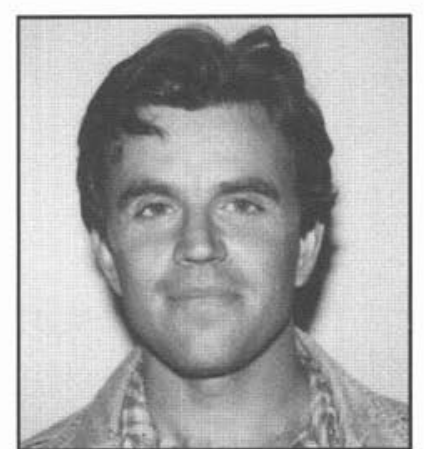

J.M. Kranabetter

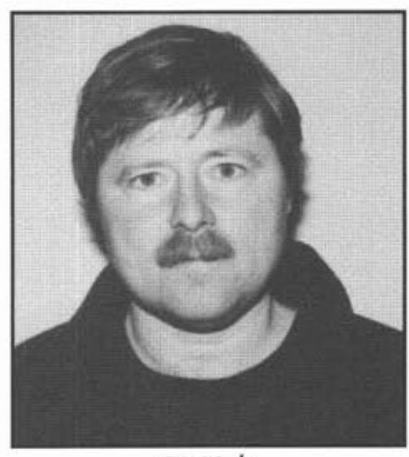

D. Yole year height and foliar results, and seventh year height increment, for lodgepole pine (Pinus contorta Dougl. ex Loud) and hybrid white spruce (Picea glauca [Moench] Voss $\times$ engelmannii Parry ex Engelmann) from this experiment.

\section{Methods \\ Study Site}

At an elevation of $1000 \mathrm{~m}$, the Regan Creek study site is transitional between a mid- and high-elevational forest (the moist/cold Sub-Boreal Spruce zone and moist/cold Englemann Spruce-Subalpine Fir zone; Banner et al. 1993), $50 \mathrm{~km}$ NE of Smithers, British Columbia $\left(54^{\circ} 49^{\prime} \mathrm{N}, 126^{\circ} 38^{\prime} \mathrm{W}\right)$. The study site had well- to moderately-well drained soils of loam to silty clay loam texture, a variable coarse fragment content (0-60\% volume), $3-8 \mathrm{~cm}$ of forest floor, and a gentle northslope gradient $(0-5 \%)$. Soils were classified as Orthic Dystric Brunisols and Brunisolic Gray Luvisols (Canadian Soil Survey Committee 1987). Growing seasons in the area are short 


\begin{tabular}{|c|c|c|}
\hline \multicolumn{3}{|c|}{ Table 1. Experimental ANOVAs } \\
\hline With split plot & & \\
\hline Source & df & Error term \\
\hline Treatment & 3 & Plot(Treat) \\
\hline Plot(Treat) & 8 & \\
\hline Species & 1 & Species*Plot(Treat) \\
\hline Species*Treat & 3 & Species*Plot(Treat) \\
\hline Species*Plot(Treat) & 8 & \\
\hline Error & $24(\mathrm{n}-1)$ & \\
\hline \multicolumn{3}{|l|}{ Without split plot } \\
\hline Source & df & Error term \\
\hline Treatment & $\overline{3}$ & Plot(Treat) \\
\hline Plot(Treat) & 8 & \\
\hline Error & $12(n-1)$ & \\
\hline
\end{tabular}

and relatively moist and cool, and are followed by cold, snowy winters (mean annual temperature and precipitation ranges from $2.2^{\circ} \mathrm{C}$ and $441 \mathrm{~mm}$ for the sub-boreal spruce zone, to $1.6^{\circ} \mathrm{C}$ and $579 \mathrm{~mm}$ for the Englemann spruce-subalpine fir zone, respectively; Banner et al. 1993).

\section{Experimental design and Treatments}

We used a nested randomized study design with a split-plot factor of tree species. Each treatment plot was approximately $30 \times 50 \mathrm{~m}$, and replicated three times, nested within the burned and unburned portion of the cutblock. The stand was harvested (ground skidded) in the winter of 1991/1992 on a deep snowpack. The four site preparation treatments were carried out in 1992 as follows:

Broadcast burn (BB) - A 12-ha portion of the block was broadcast burned while the soils and larger fuels were still very moist in June, 1992. The fine fuel moisture (FFMC) was rated 91, medium fuels (DMC) 36, and coarse fuels (DC) 176 (Muraro 1975). Approximately $40 \%$ of the slash was consumed by the fire, including almost all fine slash $(<1 \mathrm{~cm}$ diameter), while forest floor consumption averaged $1 \mathrm{~cm}$.

Disc-trenching (DT) - A TTS Delta power disc trencher mounted on a rubber-tired skidder was used. A brush blade was mounted on the front of the skidder to deflect slash from the rear discs. Average berm height was $20 \mathrm{~cm}$ after settling, and average trench depth was $15 \mathrm{~cm}$. Seedlings were planted on the disc-trench hinge.

Windrow pile and burn treatment (WP) - Slash was piled into 60 metre-long windrows, $1 \mathrm{~m}$ in height, with a Cat-180 excavator fitted with a brush rake. Windrows were burned in late October of 1992, resulting in patchy consumption of fuels. The burned windrow microsite covered $8 \%$ of the treatment area, while unburned windrow piles covered another $5 \%$. Seedlings were planted across the ash deposits and unburned forest floors.

No treatment (NT) - Plots were raw planted with no site preparation as a control. This treatment is characterized by intact forest floors and wide-spread deposits of logging slash. Logging slash averaged $9.4 \mathrm{t} / \mathrm{ha}$ for slash $<7 \mathrm{~cm}$ in diameter, and $36.1 \mathrm{t} / \mathrm{ha}$ for logs $>7 \mathrm{~cm}$ in diameter, for a total of 45.5 tonnes/ha (method in Trowbridge et al. 1986).
Table 2. Tree response to site preparation treatments

(SE below mean).

\begin{tabular}{lcccc}
\hline & BB & DT & WP & NT \\
Tree height, year 5 $(\mathrm{cm})$ & $87.7 \mathrm{a}^{*}$ & $76.9 \mathrm{~b}$ & $66.3 \mathrm{c}$ & $60.9 \mathrm{~d}$ \\
(p=0.0086) & 4.1 & 4.1 & 4.1 & 4.3 \\
Tree diameter, year 5 $(\mathrm{mm})$ & $22.6 \mathrm{a}$ & $20.2 \mathrm{~b}$ & $17.4 \mathrm{c}$ & $16.4 \mathrm{c}$ \\
(p=0.0546) & 1.4 & 1.4 & 1.4 & 1.4 \\
Height increment, year 7 $(\mathrm{cm})$ & $33.0 \mathrm{a}$ & $28.6 \mathrm{~b}$ & $25.5 \mathrm{c}$ & $21.3 \mathrm{~d}$ \\
(p=0.0075) & 1.7 & 1.7 & 1.7 & 1.7 \\
\hline
\end{tabular}

* treatment means separated by letters within rows are significantly different $(\mathrm{p}<0.05)$

Forty-nine seedlings of lodgepole pine (1+0 312 PSB) and hybrid white spruce $(2+0415$ PSB) were planted in each plot in June of 1993 at $2.5 \mathrm{~m}$ spacing. Two buffer rows were also planted around the forty-nine sample seedlings.

\section{Sampling}

We measured seedling height and root collar diameter in September of 1997, after five growing seasons in the field, and top leader length in September of 1999, after seven growing seasons. In the fall of 1997, we sampled one leader from the second whorl of 25 randomly selected seedlings and bulked these to form five composite foliar samples. We oven-dried the foliar samples at $70^{\circ} \mathrm{C}$ for 24 hours and determined the mass of 100 needles. We ground the leaves through a $2 \mathrm{~mm}$ sieve for chemical analysis. Foliar $\mathrm{N}$ was analyzed by dry combustion with the Leco CHN-600 analyzer. Macro- and micro- nutrients were analysed by ICP-AES following microwave digestion (Kalra and Maynard 1991, Carter 1993).

\section{Statistics}

Experimental results were analyzed using ANOVA (Table 1) and differences in treatment means tested with Tukey's (SAS Institute Inc. 1988), with significance levels set at 0.05 . The ANOVA was run without the split plot component if a species interaction was found.

\section{Results}

After five years, the largest trees were found on broadcast burns ( $44 \%$ increase over raw planting), followed by disc-trenching ( $26 \%$ increase), and then windrow piling ( $9 \%$ increase) (Table 2). No interaction between species and treatments was found ( $\mathrm{p}=0.7530$ ), while lodgepole pine was overall larger than hybrid white spruce ( $\mathrm{p}=0.0001$ ) (Fig. 1). Seedling diameter was significantly different across fewer treatments, with an average increase of $38 \%$ and $23 \%$, for broadcast burn and disc-trenching, respectively, over raw planting (Species*Treatment $\mathrm{p}=$ 0.3958 ; species $p=0.0001$ ). Height increment during the seventh growing season followed the same pattern as total height, with broadcast burning $55 \%$ greater than raw planting. No interaction between species and treatments was found $(\mathrm{p}=0.9684)$, while species effects were still significant $(\mathrm{p}=0.0001)$ (Fig. 2).

Equal increases in nitrogen $(\mathrm{N})$, phosphorus $(\mathrm{P})$, and sulphur (S) concentrations were found across all site preparation treatments compared to controls (Table 3). Only foliar copper $(\mathrm{Cu})$ concentrations reflected the ranking in seedling productivity across both conifer species, although all site preparation treatments were above concentrations considered possibly deficient (2.6 ppm Cu; Ballard and Carter 1986). Broadcast burning had a positive effect on foliar con- 


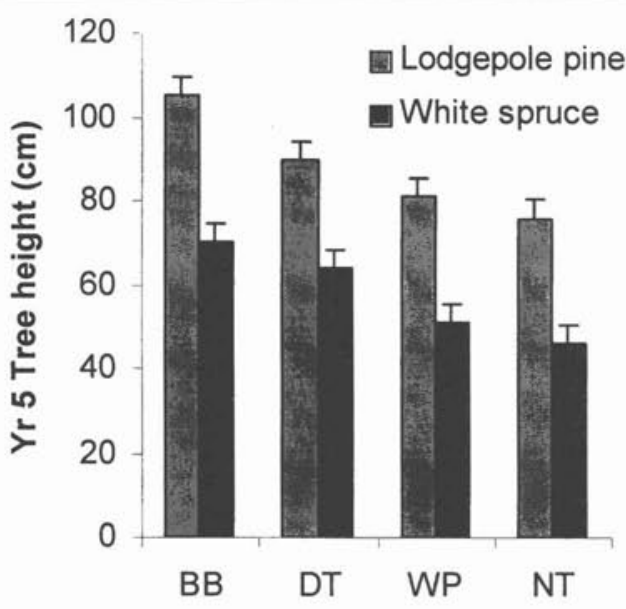

Site preparation treatment

Fig. 1. Seedling height after 5 years for lodgepole pine and hybrid white spruce across site preparation treatments. SE shown by vertical bar.

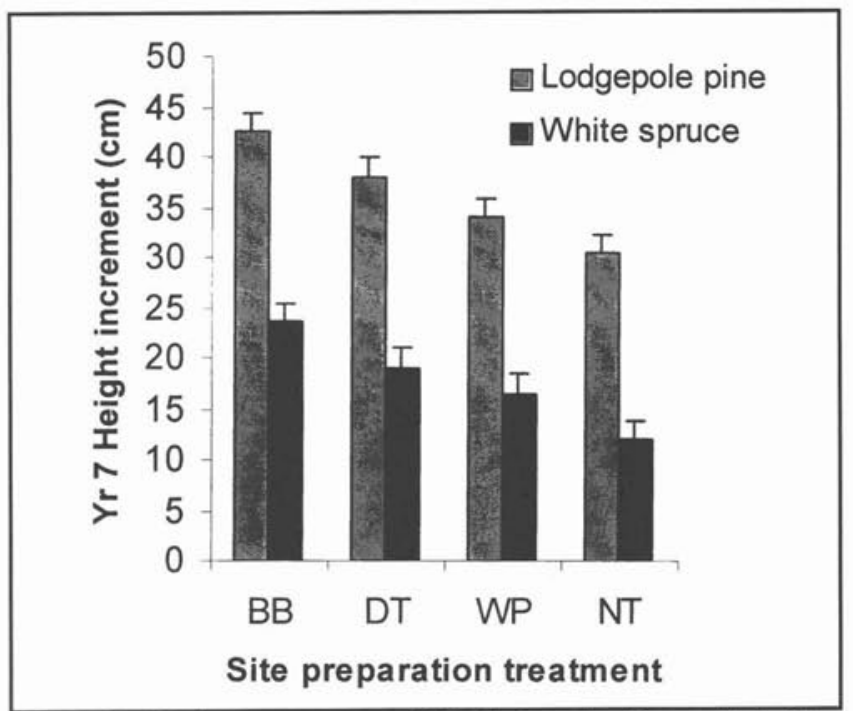

Fig. 2. Height increment at year 7 for lodgepole pine and hybrid white spruce across site preparation treatments. SE shown by vertical bar.

\begin{tabular}{|c|c|c|c|c|c|c|}
\hline & $\mathbf{N}$ & $\mathbf{P}$ & $\mathbf{S}$ & $\mathbf{K}$ & $\mathrm{Cu}$ & mass \\
\hline Treatment & $\begin{array}{c}\% \\
(\mathrm{p}=0.031)\end{array}$ & $\begin{array}{c}\% \\
(\mathrm{p}=0.006)\end{array}$ & $\begin{array}{c}\% \\
(\mathrm{p}=0.003)\end{array}$ & $\begin{array}{c}\% \\
(\mathrm{p}=0.001)\end{array}$ & $\begin{array}{c}\text { ppm } \\
(\mathrm{p}=0.019)\end{array}$ & $\begin{array}{c}\mathrm{g} \\
(\mathrm{p}=0.015)\end{array}$ \\
\hline \multirow[t]{2}{*}{ BB } & 1.25 & 0.17 & 0.077 & $0.64 a$ & $3.38 \mathrm{a}$ & $0.99 \mathrm{a}$ \\
\hline & 0.017 & 0.002 & 0.001 & 0.0085 & 0.10 & 0.026 \\
\hline \multirow[t]{2}{*}{ DT } & 1.28 & 0.16 & 0.077 & 0.54 & $3.03 \mathrm{~b}$ & $0.87 \mathrm{~b}$ \\
\hline & 0.017 & 0.002 & 0.001 & 0.0085 & 0.10 & 0.026 \\
\hline \multirow[t]{2}{*}{ WP } & 1.27 & 0.17 & 0.076 & 0.54 & $2.59 \mathrm{c}$ & $0.76 \mathrm{c}$ \\
\hline & 0.017 & 0.002 & 0.001 & 0.0085 & 0.10 & 0.026 \\
\hline \multirow[t]{2}{*}{ NT } & $1.16 \mathrm{a}^{*}$ & $0.15 \mathrm{a}$ & $0.068 \mathrm{a}$ & 0.51 & $2.50 \mathrm{c}$ & $0.77 \mathrm{c}$ \\
\hline & 0.017 & 0.002 & 0.001 & 0.0085 & 0.10 & 0.026 \\
\hline
\end{tabular}

* treatment means separated by letters within columns are significantly different $(\mathrm{p}<0.05)$

centrations of potassium (K). Needle mass was significantly different due to treatments, and the "Treatment*Species" interaction term was significant $(\mathrm{p}=0.029)$. For this reason, we also analyzed the foliar data using nutrient content $(\mathrm{mg} / 100$ needles) for each species alone (Table 4).

The foliar nutrient content for lodgepole pine increased across treatments, which corresponded to the increase in needle mass with tree size. Nutrient contents were rarely significantly different between site preparation treatments, and the trends exist for all nutrients, rather than only for those limiting tree growth. Hybrid white spruce had more consistent needle mass across treatments and therefore foliar nutrient content as well. Overall, foliar nutrient contents did not suggest the availability of growth-limiting nutrients was differentially influenced by site preparation treatments (see also Macdonald $e t$ al. 1998).

\section{Discussion}

High-elevation forests have comparatively shorter and cooler growing seasons than low-elevation forests, and temperature is usually the dominant controlling variable in these northern environments (Van Cleve and Yarie 1986). The soil disturbance resulting from mixing in disc-trenching, or partial mixing and burning in windrow piling can enhance microclimate, improve drainage, reduce vegetation competition and increase nutrient availability of the soil (McMinn and Hedin 1990, Örlander et al. 1990). Our study is limited to one site without completely random replication, but the substantial effect of site preparation on short-term tree height and increment suggest important implications for free-to-grow status and greenup restrictions on higher elevation cutblocks (British Columbia Ministry of Forests 1995a, 1995b).

Of the site preparation treatments examined, disc-trenching was the better alternative to broadcast burning, based on the increase in seedling height and increment over raw planting. We noted that machine traffic from windrow piling caused some soil compaction, which might have reduced seedling growth response (Yole and Kranabetter 1996). In other parts of central British Columbia, Bedford and Sutton (1999) found short-term increases in growth with lodgepole pine and mechanical site preparation on mesic sites. After seven years, differences in height increment still exist in our study, which might reflect longer-term benefits of site preparation in the colder, wetter conditions of these high-elevation forests.

The burning of organic matter or mixing of soil in mechanical site preparation can have short-term effects on nutrient availability, which can lead to increases in tree growth (Hawkes et al. 1990, Örlander et al. 1990). The overall increase in foliar $\mathrm{N}, \mathrm{P}$, and $\mathrm{S}$ concentrations suggested site preparation increased the availability of these nutrients over raw planting. Only $\mathrm{Cu}$ 


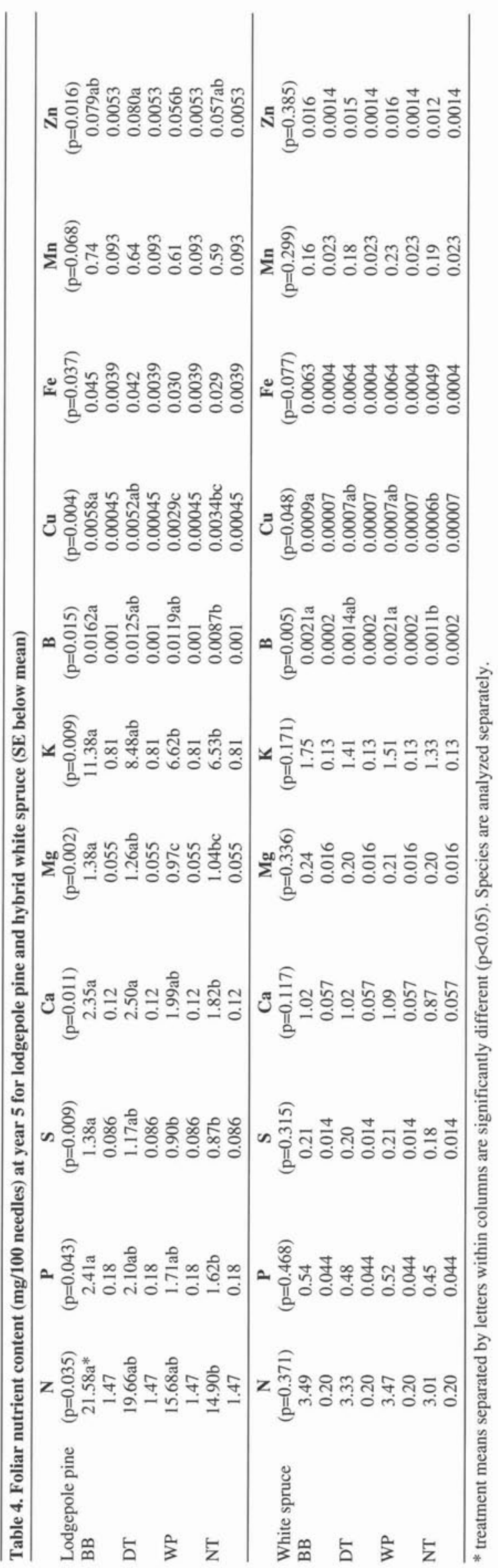

concentrations, however, reflected the significant increase in tree growth between site preparation treatments, but we were unable to find an explanation for this from other studies on seedling nutrition. Perhaps other benefits of site preparation to tree growth, such as an increase in soil temperature or growing season length, do not correspond to a simple increase in soil nutrient availability.

Forest stand renewal by fire was historically an integral part of forest dynamics in central British Columbia, so removing fire from these ecosystems is not without risk (see, for example, the ecological role of charcoal by Zackrisson et al. 1996). Operational monitoring of burns in this area found that site nutrient losses were minimal with light to moderate burns (Kranabetter and Macadam 1998). Currently most plantations in northcentral British Columbia are raw-planted, so we would expect, based on these results, at least a short-term loss in tree productivity on harsher sites. From a soil perspective, broadcast burning remains a useful tool for forest management.

\section{Acknowledgements}

We thank Anne Macadam, who was instrumental in establishing the Regan Creek research project, and Marcel Lavigne for his field and laboratory assistance. Peter Ott, advised us on statistical analysis and Clive Dawson undertook the foliar analysis.

\section{References}

Ballard, T.M. and R.E. Carter. 1986. Evaluating forest stand nutrient status. B.C. Min. For. Land Manage. Hand. 20. Queen's Printer Publications, Victoria, B.C.

Banner, A., W. MacKenzie, S. Haeussler, S. Thomson, J. Pojar and R. Trowbridge. 1993. A field guide to site identification and interpretation for the Prince Rupert Forest Region. MOF Field Handbook 26. Crown Publications, Victoria, B.C.

Bedford, L. and R.F. Sutton. 1999. Site preparation for establishing lodgepole pine in the Sub-Boreal Spruce Zone of interior British Columbia: the Bednesti trial, 10-year results. For. Ecol. (in press). British Columbia Ministry of Forests. 1995a. Forest Practices Code of British Columbia: Establishment to free growing guidebook: Prince Rupert Forest Region. Queens Printer, Victoria B.C.

British Columbia Ministry of Forests. 1995b. Forest Practices Code of British Columbia: Green-up guidebook. Queens Printer, Victoria B.C.

Canadian Soil Survey Committee. 1987. The Canadian system of soil classification. Can. Dep. Agric. Publ. 1646. Supply and Services Canada, Ottawa, Ont. 164 p.

Carter, M.R. (ed.). 1993. Soil Sampling and Methods of Analysis. Lewis Publishers, Boca Raton, Florida. 823 p.

Hawkes, B.C., M.C. Feller and D. Meehan. 1990. Site preparation: fire. In D.P. Lavender, R. Parish, C.M. Johnson, G. Montgomery, A. Vyse, R.A. Willis, and D. Winston. (eds.). Regenerating British Columbia's Forests. pp. 131-149. University of British Columbia Press. Kalra, Y.P. and D.G. Maynard. 1991. Methods manual for forest soil and plant analysis; Forestry Canada, Northwest Region, Northern Forestry Centre, Edmonton, AB. Information Report NOR-X-319. 116 p.

Kranabetter, J.M. and A. Macadam. 1998. Ten-year results from operational broadcast burning trials in northwestern British Columbia. BCMOF Research Report 15. Crown Publications, Victoria, B.C. Macdonald, S.E., M.G. Schmidt, and R.L. Rothwell. 1998. Impacts of mechanical site preparation on foliar nutrients of planted white spruce seedlings on mixed-wood boreal forest sites in Alberta. For. Ecol. And Man. 110: 35-48. 
Miller, R.E. and K.W. Seidel. 1990. Effects of prescribed fire on timber growth and yield. In J.D. Walstad, S.R. Radosevich, D.V. Sandberg (eds.). Natural and prescribed fire in Pacific Northwest forests. pp. 177-188. Oregon State University Press.

McMinn, R.G. and I.B. Hedin. 1990. Site preparation: mechanical and manual. In D.P. Lavender, R. Parish, C.M. Johnson, G. Montgomery, A. Vyse, R.A. Willis, and D. Winston. (eds.). Regenerating British Columbia's Forests. pp. 150-163. University of British Columbia Press.

Muraro, S.J. 1975. Prescribed Fire Predictor/Planner. Can. For. Serv., Pac. For. Res. Cent., Victoria, B.C.

Örlander, G, P. Gemmel and J. Hunt. 1990. Site preparation. A Swedish overview. FRDA report 105, British Columbia Ministry of Forests.

Örlander, G., G. Egnell, A Albrektson. 1996. Long-term effects of site preparation on growth in Scots pine. For. Ecol. And Man. 86: 27-37.

SAS Institute Inc. 1988. SAS/STAT user's guide. Release 6.03 ed. Cary, N.C.

Stein, W.I. 1997. Ten-year survival and growth of planted Douglasfir and western redcedar after seven site-preparation treatments. West. J. of Appl. For. 12(3): 74-80.
Trowbridge, R., B. Hawkes, A. Macadam, and J. Parminter. 1986. Field handbook for prescribed fire assessments in British Columbia: logging slash fuels. Land Management Handbook 11. B.C. Ministry of Forests, Canadian Forestry Service. Victoria, B.C.

Van Cleve, K. and J. Yarie. 1986. Interaction of temperature, moisture and soil chemistry in controlling nutrient cycling and ecosystem development in the Taiga of Alaska. In K. Van Cleve, F.S. Chapin III, L.A. Viereck, C.T. Dyrness and P.W. Flanagan. (eds.). Forest Ecosystems in the Alaskan Taiga: A Synethesis of Structure and Function. pp. 160-189. Ecological Studies 57. Springer-Verlag, New York.

Yole, D. and J.M. Kranabetter. 1996. Effects of site preparation treatments on soil properties - alternatives to broadcast burning in the north-central interior. FRDA memo 230. Crown Publications, Victoria, B.C.

Zackrisson, O., M. Nilsson, and D.A. Wardle. 1996. Key ecological function of charcoal from wildfire in the Boreal forest. Oikos 77: 10-19. 